\title{
Translocation of Klebsiella sp. in mice fed an enteral diet containing prebiotics
}

\author{
Translocação de Klebsiella sp. em camundongos \\ alimentados com dieta enteral contendo prebióticos
}

Daniele Ferreira da SILVA'

José Mário da Silveira MEZÊNCIO²

Maria Cristina Dantas VANETTI ${ }^{1}$

Paulo Roberto CECON ${ }^{3}$

Matheus Loureiro dos SANTOS 1

A B S T R A C T

\section{Objective}

This work aimed to evaluate the effect of fructooligosaccharide and inulin added to an enteral diet on the translocation of Klebsiella sp. in mice.

\section{Methods}

Four- to six-week-old Swiss albino mice were divided into nine groups and fed enteral diets containing different combinations of fructooligosaccharide, inulin, antibiotic and corticoid, inoculated or not with Klebsiella pneumoniae. On day 5, the animals of four groups were fed an enteral diet contaminated with approximately $10^{10} \mathrm{CFU} / \mathrm{g}$ of $\mathrm{K}$. pneumoniae. At defined times, two animals of each group were sacrificed and their organs (spleen, heart, liver, lungs, and kidneys) were aseptically collected, weighed, and analyzed for the presence of typical Klebsiella sp. colonies.

\section{Results}

A higher number of CFU/g of Klebsiella was detected in the organs of the animals in the immune-suppressed group fed the diet contaminated with K. pneumoniae and without prebiotics. Animals fed the diet enriched with fructooligosaccharide and inulin, at a concentration of $15.3 \mathrm{mg} / \mathrm{g}$ of body weight, had a shorter period of Klebsiella sp. translocation, compared with those not fed prebiotics in the diet.

\section{Conclusion}

The addition of fructooligosacharide and inulin in enterais diets at a concentration of $15.3 \mathrm{mg} / \mathrm{g}$ of body weight resulted in the reduction of translocation of Klebsiella for spleen, heart, liver, lung and kidneys of mice that had received the diet contaminated associated or not with antibiotic and imunodepressor drug.

Indexing terms: Inulin. Klebsiella sp. Enteral nutrition. Bacterial translocation.

\footnotetext{
${ }^{1}$ Universidade Federal de Viçosa, Departamento de Microbiologia. Av. P.H. Rolfs, s/n., 36570-000, Viçosa, MG, Brasil.

Correspondência para/Correspondence to: J.M.S. MEZÊNCIO. E-mail: <jmsmezencio@yahoo.com.br>.

2 Universidade Federal de Viçosa, Departamento de Biologia Geral. Viçosa, MG, Brasil.

3 Universidade Federal de Viçosa, Departamento de Ciência da Computação. Viçosa, MG, Brasil.
} 


\section{RE S U M O}

\section{Objetivo}

Avaliar o efeito da administração de frutooligossacarídeo e inulina, adicionados à dieta enteral, na translocação de Klebsiella sp. em camundongos.

\section{Métodos}

Camundongos albinos suíços, com quatro a seis semanas de vida, foram divididos em nove grupos e tratados com dietas enterais contendo diferentes combinações de frutooligossacarídeos, inulina, antibiótico e corticóide, inoculadas ou não com Klebsiella pneumoniae. No quinto dia de experimento, os animais dos tratamentos IV, V, VIII e IX foram alimentados com dieta enteral contaminada com, aproximadamente, 10 10 UFC/g de Klebsiella pneumoniae. Em tempos definidos (sexto, sétimo, nono, décimo primeiro e décimo terceiro dia de experimento), dois animais de cada grupo foram sacrificados e seus órgãos: baço, coração, fígado, pulmões e rins, foram coletados assepticamente, pesados e analisados quanto à presença de colônias típicas de Klebsiella sp.

\section{Resultados}

Maior número de UFC/g de Klebsiella sp. foi detectado em órgãos de animais do grupo imunodeprimidos, que receberam dieta com Klebsiella pneumoniae e sem prebióticos. Animais que receberam dieta enriquecida com frutooligossacarídeo e inulina, na concentração de 15,3mg/g de peso corporal, apresentaram menor período para a translocação de Klebsiella sp., quando comparados aos animais que não receberam prebióticos na dieta.

\section{Conclusão}

A adição de frutooligossacarídeos e inulina em dietas enterais na dose de 15,3mg/g de peso corporal resultou na diminuição de translocação de Klebsiella para baço, coração, fígado, pulmão e rins de camundongos que receberam a dieta contaminada associada ou não com droga imunodepressora e antibiótico.

Termos de indexação: Inulina. Klebsiella sp. Nutrição enteral. Translocação bacteriana.

\section{INTRODUCTION}

Gram-negative bacteria present in the intestinal microbiota, such as Klebsiella pneumoniae, an opportunistic pathogen, are frequently recovered from patients and considered to cause hospital infections ${ }^{1,2}$. Klebsiella is also one of the bacteria most frequently found contaminating enteral diets and is a likely source of infection in immune-suppressed individuals ${ }^{3,4}$. This organism's ability to translocate from the intestinal tract to other organs of the body is known, being among the enterobacteria that translocate the most ${ }^{5,6}$. Translocation seems to occur more easily in immune-suppressed patients, who make use of antibiotics and/or have some intestinal epithelial injury ${ }^{6}$. Experimental studies suggest that bacterial translocation may be reduced by an enteral supply of nutrients to the colon, e.g., fermentable fibers ${ }^{7}$. Inulin and fructooligosaccharides (FOS) are considered prebiotic ingredients because they benefit the host by stimulating selective growth and/or the metabolic activity of a limited number of bacteria in the colon ${ }^{8,9}$. Bifidobacteria ferment the fibers in the colon, producing a number of nutrients, including short chain fatty acids, such as acetate, propionate, and butyrate, which stimulate mucosal growth $^{10}$. They also reduce bacterial translocation and stimulate intestinal immune defense ${ }^{11}$. Since virulent strains of Klebsiella may contaminate enteral diets, this work aimed to evaluate, in vivo, the effect of adding prebiotics to an enteral diet on the translocation of Klebsiella to different organs.

\section{METHODS}

K. pneumoniae recovered from an enteral diet by Pereira ${ }^{12}$ was activated in Trypticase Soy Broth (TSB, Merck) at $37^{\circ} \mathrm{C}$, for $24 \mathrm{~h}$ and the cells were collected by centrifugation. The Klebsiella cell concentrate was diluted with saline $(0.85 \%$ $\mathrm{NaCl})$ to obtain a suspension containing around $10^{10}$ colony-forming-units (CFU) per milliliter of enteral diet.

The enteral diet used was Soya Diet without sucrose (Support ${ }^{\circledR}$ ). The powdered diet 
was dissolved in sterile distilled water according to the manufacturer's recommendations. The enteral diet fed to the animal groups receiving the prebiotics was prepared by adding $15.3 \mathrm{mg} /$ $100 \mathrm{~g}$ of body weight per day of FOS and $15.3 \mathrm{mg} /$ $100 \mathrm{~g}$ of body weight per day of inulin, considering a mean animal weight of $24 \mathrm{~g}$ and a daily average intake of approximately $20 \mathrm{~mL}$ of diet per animal. The animals in the control group were fed the $\operatorname{diet}$ AIN-93G, ad libitum ${ }^{13}$.

Four- to six-week-old Swiss albino mice were used, randomly separated in groups of 10 animals and kept in disinfected cages, at a room temperature of $25^{\circ} \mathrm{C}$.

The experiment was performed in a completely randomized design, repeated twice, following a split-plot design with the treatments in the plots, shown in Chart 1, and the evaluation times in the split plots.

The immune system was suppressed from the start until the end of the experiment by administering $10 \mathrm{mg} / \mathrm{kg}$ of prednisone to the animals, as well as $200 \mathrm{mg} / \mathrm{kg}$ of carbenicillin orally during the first four days of the experiment. The enteral diet contaminated with $10 \mathrm{CFU} / \mathrm{mL}$ of Klebsiella was also supplied on day 5 to the animals in groups IV, V, VIII, and IX (Chart 1).

On days 6, 7, 911 , and 13, two animals of each group were killed and organs such as heart, liver, spleen, kidneys and lungs were collected, weighed, and stored at $4^{\circ} \mathrm{C}$ for 24 hours in sterile polyethylene bags (Whirl-Pak, Millipore). Typical colonies of Klebsiella were counted by macerating the organs ${ }^{14}$, preparing decimal dilutions and inoculating them in MacConkey-InositolCarbenicillin (Merck) selective agar, followed by incubation at $37^{\circ} \mathrm{C}$ for 48 hours ${ }^{15}$. The result was expressed in CFU of Klebsiella per gram of organ. Only the plates containing more than 25 colonies were included.

The researchers were aware of the ethical and legal requirements and regulations for researches done in Brazil and of the Colégio Brasileiro de Experimentação Animal (COBEA - Brazilian College of Animal Experimentation).

\section{RE S U L T S}

Typical colonies of Klebsiella sp. in selective McConkey-Inositol-Carbenicillin medium were not found in the liver, spleen, heart, kidneys, and lungs of the animals in treatments I, II and VI, which were not given immune-suppressing medication or contaminated diet.

On day 6 , around $10^{5}$ typical CFU/g of Klebsiella sp. were found in the liver (Figure 1A) of treatment III immune-suppressed animals fed the uncontaminated enteral diet. Klebsiella sp. was also recovered from the kidneys, liver, and spleen of these animals on day 7 (Figure A).

Chart 1. Characteristics of the different treatments given to the animals. Viçosa (MG), 2004.

\begin{tabular}{ll}
\hline Treatment & Characteristics \\
\hline I & Diet AIN-93G (13) and healthy animals \\
II & Enteral diet with prebiotics, uncontaminated, healthy animals \\
III & Enteral diet with prebiotics, uncontaminated, immune-suppressed animals \\
V & Enteral diet with prebiotics, contaminated, healthy animals \\
V & Enteral diet with prebiotics, contaminated, immune-suppressed animals \\
V & Enteral diet without prebiotics, uncontaminated, healthy animals \\
VII & Enteral diet without prebiotics, uncontaminated, immune-suppressed animals \\
VIII & Enteral diet without prebiotics, contaminated, healthy animals \\
IX & Enteral diet without prebiotics, contaminated, immune-suppressed animals \\
\hline
\end{tabular}


When immune-suppressed animals were given an enteral diet without $K$. pneumoniae and addition of prebiotics (treatment $\mathrm{VI}$ ), translocation of indigenous Klebsiella was also confirmed and organs such as spleen, liver, and lungs had from $10^{3}$ to $10^{5} \mathrm{CFU} / \mathrm{g}$ (Figure 1B).

The addition of the prebiotics FOS and inulin to the enteral diet contaminated with $K$. pneumoniae did not prevent Klebsiella translocation in healthy animals (treatment IV).

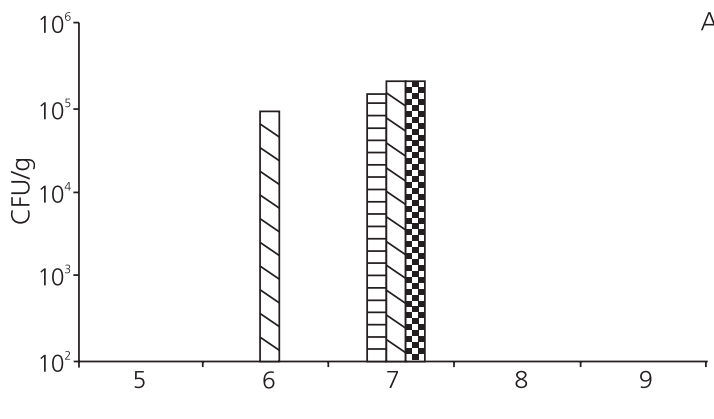

Day
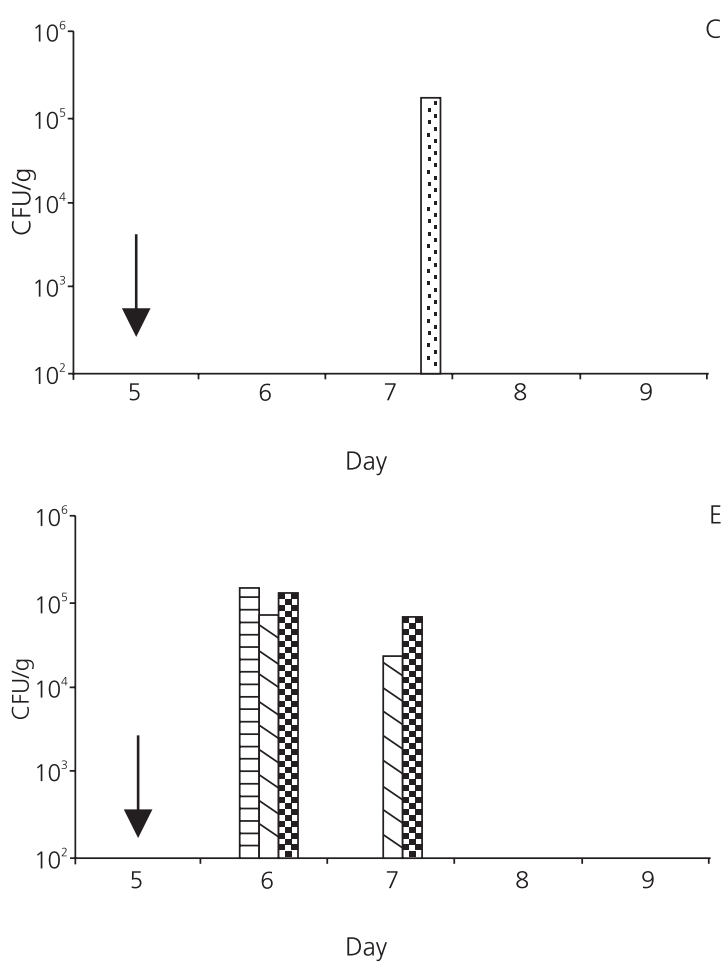

$C$

$E$
However, when healthy animals were given a contaminated diet without prebiotics (treatment VIII), the Klebsiella count was much higher in the organs analyzed and lasted longer (Figure $1 C$ and D).

The treatment $\mathrm{V}$ immune-suppressed animals given a contaminated enteral diet with prebiotics had $10^{4}$ to $10^{5} \mathrm{CFU} / \mathrm{g}$ of Klebsiella sp. in the kidneys, liver and spleen (Figure 1E). Translocation for a period of up to 9 days was

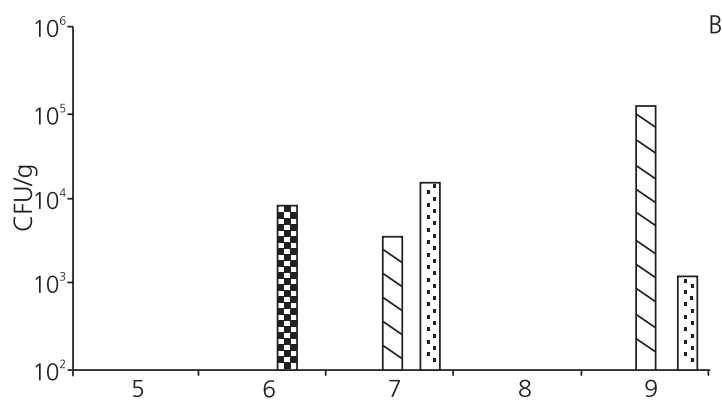

Day
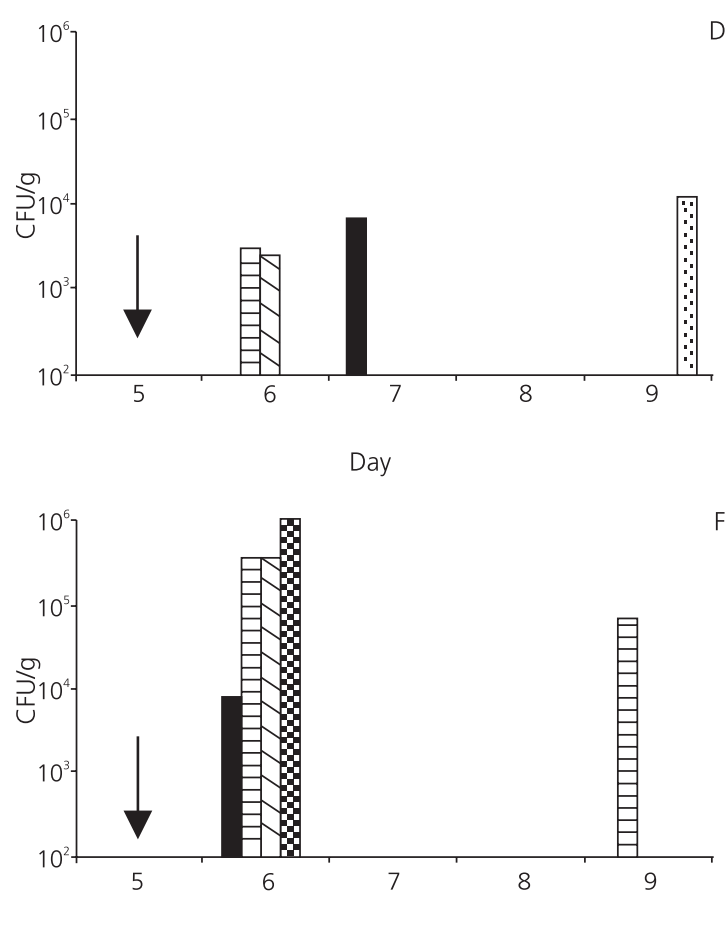

Day 
confirmed in the immune-suppressed animals of treatments VII, VIII and IX fed either the contaminated or uncontaminated diet with prebiotics. The treatment IX animals presented the highest CFU/g values of typical Klebsiella colonies, around $10^{6} \mathrm{CFU} / \mathrm{g}$. Prebiotics in the diet were more effective in reducing the translocation period than in reducing the number of translocated cells.

\section{DISCUSSION}

The results obtained from the animals in treatments I, II, and VI suggest that in uninoculated hosts with an effective immune system, digestive tract indigenous Klebsiella are unable to translocate to the analyzed organs.

The translocation of Klebsiella sp. observed in the different organs reinforces Berg's ${ }^{5}$ statement: $K$. pneumoniae is one of the bacterial species which translocates most from the intestinal tract of mice given prednisone and other immune-suppressing drugs.

The liver was the organ most often contaminated with Klebsiella sp. (Figure 1A, B, $D, E$ and F) and this may be attributed to the large number of bacteria passing from the intestinal mucosa to the portal system, necessarily passing through the liver lobes before reaching the systemic circulation ${ }^{16}$. Pereira ${ }^{12}$ also observed that the K. pneumoniae strain P15 translocated more frequently to the liver than to other organs in immune-suppressed animals.

The presence of bacteria in response to immune changes, as verified in the uninoculated, immune-suppressed animals of treatments III and VII, corroborates the findings of other authors. Gianotti et al. ${ }^{17}$ suggested that prednisone therapy can modulate the intestinal barrier function of the host and also decrease the survival of thermally injured mice, with more translocation of exogenous and indigenous enteric bacteria to vital organs. Pereira ${ }^{12}$ found strains of Klebsiella genetically distinct from those ingested in the organs of mice whose immune systems had been suppressed with prednisone. According to Alverdy and Aoys ${ }^{18}$, corticosteroid treatment significantly reduces secretory IgA concentration in the intestine. Jones et al..$^{19}$ found that increasing doses of corticoids prolonged the presence of indigenous and exogenous bacteria in the tissues of mice. They also observed that prednisone can increase the adherence of these bacteria to the intestinal cells facilitating their translocation, besides reducing the host's ability to eliminate the translocated bacteria. This fact is confirmed when the animals of treatment VII (uncontaminated enteral diet without prebiotics given to immune-suppressed animals) are compared with those of treatment $\mathrm{VI}$ (uncontaminated enteral diet without prebiotics given to healthy animals). These results suggest that the translocation seen in the animals of treatment VII may have been eased by combining prednisone with antibiotic.

The concomitant use of immunesuppression, antibiotic and a contaminated enteral diet increased the bacterial translocation process, confirmed by the results obtained from the animals in treatments IV (contaminated enteral diet with prebiotics given to healthy animals), $\mathrm{V}$ (contaminated enteral diet with prebiotics given to animals treated with prednisone and carbenicillin), VIII (contaminated enteral diet without prebiotics given to healthy animals) and IX (contaminated enteral diet without prebiotics given to animals treated with prednisone and carbenicillin). The results were in agreement with the literature which stated that there is an increase in translocation rate when a combination of two or three mechanisms responsible for translocation occurs ${ }^{6,15}$.

The data regarding the use of prebiotics in the diet is in agreement with a number of published studies. Inulin and FOS are indigestible oligosaccharides classified as dietary fibers and functional ingredients ${ }^{8,20,21}$. The target of their functional effect is the colonic microbiota which is capable of fermenting them and for which they act as selective agents of gastrointestinal

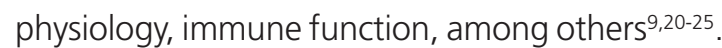
The scientific data exposed in this work show a strong evidence of the prebiotic effect of FOS and 
inulin, since they decrease the risk of translocation of an opportunistic pathogen in animals given contaminated foods and immune-suppressing drugs.

In view of the risk of enteral diets being contaminated with bacteria that pose a threat to patients taking corticoids and antibiotics, prebiotics should become one of the basic ingredients of enteral diets because of their fundamental protective role.

\section{CONCLUSION}

Animals fed FOS and inulin $(15.3 \mathrm{mg} / 100 \mathrm{~g}$ a day) had shorter periods of translocation than animals not fed prebiotics.

\section{COLLABORATORS}

D.F. SILVA: Literature review, research, data analysis and writing of the article. J.M.S. MEZENCIO: Research advisor, data analysis and correction of the article. M.C.D. VANETTI: Research co-advisor, data analysis and correction of the article. P.R. CECON: Research co-advisor, data analysis and correction of the article. M.L. SANTOS: Research, data analysis and writing of the article.

\section{REFERENCES}

1. Gales AC, Sader HS, Jones RN. Respiratory tract pathogens isolated from patients hospitalized with suspected pneumonia in Latin America: frequency of occurrence and antimicrobial susceptibility profile. Results from SENTRY Antimicrobial Surveillance Program (1997-2000). Diag Microbiol Infect Dis. 2002; 44(3):301-11.

2. Mehall JR, Kite CA, Saltzman DA, Wallett T, Jackson RJ, Smith SD. Prospective study of incidence and complications of bacterial contamination of enteral feeding in neonates. J Ped Surg. 2002; 37(8): 1177-82.

3. Oliviera MH, Bonelli R, Aidoo KE, Batista RV. Microbiological quality of reconstituted enteral formulations used in hospitals. Nutrition. 2000; 16(9):729-33.

4. Pinto UM, Cardoso RR, Vanetti MCD. Detecção de Listeria, Salmonella e Klebsiella em serviço de alimentação hospitalar. Rev Nutr. 2004; 17(3): 319-26.

5. Berg RD. Bacterial translocation from the gastrointestinal tracts of mice receiving immunosuppressive chemotherapeutic agents. Curr Microbiol. 1983; 8(5):879-82.

6. Wiest R, Rath HC. Bacterial translocation in the gut. Best Prac Res Clin Gastroenterol. 2003; 17(3): 397-425.

7. Kapkac M, Erikoglu M, Tuncyurek P, Ersin S, Esassolak M, Alkanal M, et al. Fiber enriched diets and radiation induced injury of the gut. Nutr Res. 2003; 23(1):77-83.

8. Gibson GR, Roberfroid MB. Dietary modulation of the human colonic microflora: introducing of prebiotics. J Nutr. 1995; 125(6):1401-12.

9. Kaplan H, Hutkis RW. Fermentation of fructooligosaccharides by lactic acid bacteria and bifidobacteria. Appl Environ Microbiol. 2000; 66(6): 2682-4.

10. Guarner F, Malagelada JR. Gut flora in health and disease. Lancet. 2003; 361(9356):512-9.

11. Rayes N, Hansen S, Seehofer D, Müller AR, Serke S, Bengmark $S$, et al. Early enteral supply of fiber and lactobacilli versus conventional nutrition: a controlled trial in patients with major abdominal surgery. Nutrition. 2002; 18(7/8):609-15.

12. Pereira SCL. Caracterização molecular e de fatores de virulência de Klebsiella sp. isoladas de dietas enterais [tese]. Viçosa: Universidade Federal de Viçosa; 2001.

13. Reeves PG, Nielsen RH, Fahey GC Jr. AIN-93 purified diets for laboratory rodents: final report of the American Institute of Nutrition ad hoc committee on the reformulation of the AIN-76A rodent diet. J Nutr. 1993; 123(11):1939-51.

14. Nader de Macíaz ME, Apella MC, Romero NC, González SN, Oliver G. Inhibition of Shigella sonnei by Lactobacillus casei and Lactobacillus acidophilus. J Appl Bacteriol. 1992; 73(5):407-11.

15. Berg RD. Bacterial translocation from the gastrointestinal tract. Trends Microbiol. 1995; 3(4):149-54.

16. Bagley ST, Seidler RJ. Primary Klebsiella identification with MacConkey-Inositol-Carbenicillin agar. Appl Environ Microbiol. 1978; 36(3):536-8.

17. Gianotti L, Alexander JW, Fukushima R, Pyles T. Steroid therapy can modulate gut barrier function, host defense, and survival in thermally injured mice. J Surg Res. 1996; 62(1):53-8.

18. Alverdy J, Aoys E. The effect of glucocorticoid administration on bacterial translocation. Am Surg. 1991; 214(6):719-23. 
19. Jones WG, Barber AE, Kapur S, Hawes AJ, Fahey TJ, Minei JP, et al. Pathophysiologic glucocorticoid levels and survival of translocating bacteria. Arch Surg. 1991; 126(1):50-5.

20. Roberfroid MB, van Loo JAE, Gibson GR. The bifidogenic nature of chicory inulin and its hydrolysis products. J Nutr. 1998; 128(1):11-9.

21. Manning TS, Gibson GR. Prebiotics. Best Prac Res Clin Gastroenterol. 2004; 18(2):287-98.

22. Roberfroid, M. Functional food concept and its application to prebiotics. Dig Liver Dis. 2002; 34(2): S105-S10.

23. Wile TV, Boon N, Possemiers S, Jacobs H, Verstraete W. Prebiotic effects of chicory inulin in the simulator of the human intestinal microbial ecosystem. FEMS Microbiol Ecol. 2004; 51(1): 143-53.
24. Montesi A, Garcia-Albiach RG, Pozuelo MJ, Pintado C, Goni I, Rotger R. Molecular and microbiological analysis of caecal microbiota in rats fed with diets supplemented either with prebiotics or probiotics. Int J Food Microbiol. 2005; 98(3):281-9.

25. Rinne M, Gueimonde M, Kalliomäki M, Hoppu U, Salminen SJ, Isolauri E. Similar bifidogenic effects of prebiotic-supplemented partially hydrolyzed infant diet and breastfeeding on infant gut microbiota. FEMS Immunol Med Microbiol. 2005; 43(1):59-65.

Received on: 9/5/2007

Final version resubmitted on: 18/7/2008

Approved on: 8/9/2008 